\title{
Holiness and humour
}

\begin{tabular}{|c|c|}
\hline \multicolumn{2}{|l|}{$\begin{array}{l}\text { Author: } \\
\text { Anita Houck }\end{array}$} \\
\hline \multicolumn{2}{|c|}{$\begin{array}{l}\text { Affiliations: } \\
\text { }{ }^{1} \text { Saint Mary's College, } \\
\text { Notre Dame, Indiana, } \\
\text { United States of America }\end{array}$} \\
\hline \multicolumn{2}{|c|}{$\begin{array}{l}\text { 2Department of New } \\
\text { Testament Studies, Faculty of } \\
\text { Theology, University of } \\
\text { Pretoria, South Africa }\end{array}$} \\
\hline \multicolumn{2}{|c|}{$\begin{array}{l}\text { Project leader: A.G. van Aarde } \\
\text { Project number: } 2334682\end{array}$} \\
\hline \multicolumn{2}{|c|}{$\begin{array}{l}\text { Description: } \\
\text { Prof Dr. Anita Houck is chair } \\
\text { and associate Professor of } \\
\text { Religious Studies at St Mary's } \\
\text { College, Notre Dame, } \\
\text { Indiana, and is part of the } \\
\text { research project, 'Biblical } \\
\text { Theology and Hermeneutics: } \\
\text { Holiness', directed by Prof Dr. } \\
\text { Andries van Aarde, professor } \\
\text { emeritus and senior research } \\
\text { fellow in the Faculty of } \\
\text { Theology of the University of } \\
\text { Pretoria, South Africa. }\end{array}$} \\
\hline \multicolumn{2}{|c|}{$\begin{array}{l}\text { Corresponding author: } \\
\text { Anita Houck, } \\
\text { ahouck@saintmarys.edu }\end{array}$} \\
\hline \multicolumn{2}{|c|}{$\begin{array}{l}\text { Received: } 06 \text { May } 2016 \\
\text { Accepted: } 09 \text { Aug. } 2016 \\
\text { Published: } 30 \text { Sept. } 2016\end{array}$} \\
\hline \multicolumn{2}{|c|}{$\begin{array}{l}\text { How to cite this article: } \\
\text { Houck, A., 2016, 'Holiness } \\
\text { and humour', HTS Teologiese } \\
\text { Studies/Theological Studies } \\
72(4) \text {, a3464. http://dx.doi. } \\
\text { org/10.4102/hts.v72i4.3464 }\end{array}$} \\
\hline \multicolumn{2}{|c|}{$\begin{array}{l}\text { Copyright: } \\
\text { (c) 2016. The Authors. } \\
\text { Licensee: AOSIS. This work } \\
\text { is licensed under the } \\
\text { Creative Commons } \\
\text { Attribution License. }\end{array}$} \\
\hline \multicolumn{2}{|l|}{ Read online: } \\
\hline 口idn & $\begin{array}{l}\text { Scan this QR } \\
\text { code with your } \\
\text { smart phone or } \\
\text { mobile device } \\
\text { to read online. }\end{array}$ \\
\hline
\end{tabular}

Although Christian spirituality includes a long tradition of suspicion of humour, humour can express and further holiness in several ways. Humour serves holiness in religious satire; it can also communicate the self-transcendent perspective of holy women and men. Humour and holiness can also illuminate each other because both are inherently relational. Christian holiness consists primarily in right relationship to the Holy One and, thus, to others. Humour's complex relational nature is examined with the help of Ted Cohen's analysis of joke-telling and evolutionary and cognitive research. Humour and its primary expression, laughter, are inherently ambiguous, capable of expressing and creating a range of attitudes and relationships; consequently, they can both conduce to and hinder holiness. Finally, humour can contribute to the religious imagination, and thus to holiness, by challenging established images of the holy, inviting fresh theological reflection, and inspiring ethical action. Both holiness and humour require openness to that which is beyond us and agility in responding to the other.

\section{Introduction}

Perhaps the easiest way to connect humour and holiness is through satire. Satire has been spotting pretenders to holiness for centuries, from Aristophanes and Erasmus to the anti-homophobic posts on God's Facebook page and The Onion's frequent wrestlings with theodicy ('God diagnosed with bipolar disorder', 'Pope Francis worried about job security after butting heads with new God', 'God admits he way less strict with last few billion children'). We know holiness can be lax or feigned, and we know that the structures of religion can favour saintly appearance over spiritual reality. Humour helps us to be vigilant about such hypocrisy. A contemporary example, a joke told in longer and no doubt better form by Bishop Kevin Dowling of Rustenburg, illustrates one of satire's greatest tools: by belabouring details, it exaggerates the truth so that we can see it more easily:

A bishop heard that one of his priests had a reputation of spending very little time in prayer and spirituality, and instead enjoying the good things in life. So he decided he would make a personal visitation to the priest. The priest - suspecting what this was all about - embarked on his own particular strategy.

The bishop arrived in the afternoon. The priest met him, chatted for a while, and invited the bishop to join him in 30 minutes of meditation, ending in Evening Prayer. After that, the housekeeper brought each supper, which consisted of a fried egg, a slice of dry toast, and a cup of black tea.

After some conversation about the challenges of ministry in the parish, the priest asked the bishop to return to the chapel for Night Prayer, after which they both retired to bed.

At two in the morning, the bishop was awakened by the priest summoning him to the chapel for the Office of Readings. He was awakened again at 5.30 a.m. for meditation and Morning Prayer. After that, the housekeeper brought each breakfast, consisting of a boiled egg, a piece of dry toast, and a cup of black tea. Then the priest asked the bishop to accompany him as he visited the local Catholic school and several sick and elderly members of the parish. They skipped lunch, shared midday prayer, and headed out again, visiting several families till they came back to the church for evening meetings with the catechists and the parish council. After Evening Prayer and Meditation in the chapel, the housekeeper brought them supper, which consisted of a bowl of soup, a slice of dry toast, and a cup of black tea. The bishop told the priest that he was very happy with the visit, encouraged him in his ministry, and said that he would now return to his own house.

The next morning the housekeeper remonstrated with the priest, saying: 'We never get a visit from the bishop, and I could have prepared wonderful meals for both of you ... but look what you asked me to cook - eggs, dry toast, and black tea!' The priest answered her: 'Ah, my dear, did you never read what Jesus said in the Gospel: "Such devils can only be cast out by prayer and fasting!"' (Dowling 2015)

This particular piece of satire, to which we will return, recommends itself especially for a study of holiness and humour. Firstly, it represents a venerable spiritual tradition of remonstrating those who judge others. As Anthony Godzieba points out, it echoes a story from the Verba Seniorum in which a group of cenobites interprets hermetic hospitality as a sign of sensory indulgence. After 
overhearing the cenobites commenting, 'These hermits eat more than we do in the monastery', the host sends them on to a brother hermit with the message, 'Be careful not to water the vegetables'. Treated to more asceticism than they can abide, they sneak off in the dark (Godzieba 2015; Merton 1960:27-28). Secondly, the contemporary story represents humour's use in self-examination. Told by a bishop at the expense of bishops, it suggests that self-deprecatory humour can serve as a means towards holiness.

Once we move beyond the obvious work of satire, however, the question of how humour may be connected to holiness seems more complex, even fraught. Hugo Rahner explains the persistence of the problem in Christianity:

\begin{abstract}
... may a Christian laugh, when he has heard our Lord's warning, 'Woe upon you who laugh now; you shall mourn and weep' (Luke 6.25)? May a Christian go on merrily playing when a stern and strict choice has to be made for eternity? Is it right for him to relax, to ease the senses, when experience constantly reminds him how these same senses draw him down? All these are questions which the Fathers of the Church raised solemnly and seriously, which Aquinas tried to answer after mature and enlightened reflection, which were brought to a head in the bitter controversies between the Jansenists and the 'devout humanists' with their ideas of a heaven on earth. They are questions which are raised in a completely new form today, when we are concerned with the thorny problem of the 'Christian in the world', with discovering a mean between accepting and rejecting joyous, refreshing, relaxing things, between gravity and playfulness, crying and laughing. (Rahner 1965 [1963]:92)
\end{abstract}

As Rahner shows, suspicion of humour has a history as long and illustrious as satire's. Paul, Jerome, Chrysostom (both the saint and the pseudo), Augustine, Basil, Bernard and Aquinas all set limits on wit and laughter, with some basing their views on the gospels' testimony that Christ wept but never laughed (Screech 1999:47, 135-136). Among modern thinkers, perhaps the best-known reflection on what humour means to Rahner's 'Christian in the world' is Reinhold Niebuhr's. In his essay 'Humour and faith', Niebuhr acknowledges humour's virtues, noting that at its best it is 'proof of the capacity of the self to gain a vantage point from which it is able to look at itself', 'a by-product of self-transcendence' and the 'prelude to the sense of contrition' (Niebuhr 1946:119-120). He even welcomes laughter as 'the beginning of prayer' (Niebuhr 1946:111). But he also draws a boundary beyond which laughter and humour cannot go:

Laughter must be heard in the outer courts of religion; and the echoes of it should resound in the sanctuary; but there is no laughter in the holy of holies. There laughter is swallowed up in prayer and humour is fulfilled by faith. (Niebuhr 1946:111-112)

For Niebuhr, humour may help Christians remember that they are in the world but not of it, but the holy must be met in seriousness.

The way through this complexity is to acknowledge that both holiness and humour are primarily relational, and to examine their connections according to the way each expresses and shapes relationships. We know some things about how relationships work, and, with its inherent interdisciplinarity, spirituality can benefit from the insights of numerous perspectives on this complex topic. Literature, cognitive science, theology and anthropology are among the resources available to students of spirituality, and they can serve students of humour equally well. By drawing on these approaches to understand the relational nature of humour, we find that both holiness and humour require what Niebuhr might well call 'self-transcendence', in particular an openness to what is beyond oneself and an agility in responding to the other.

\section{Sabbath, beer and martyrdom: Relationship in humour and holiness}

Although the holy is sometimes perceived as that which is set apart - sacred spaces, blessed objects, extraordinary people holiness exists only in relationship. Nothing is holy in or by itself. A power that is holy in one context is polluting in another, and without connection to the transcendent, holiness becomes mere magic. In Christian spirituality, holiness resides in right relationship to the Holy One. Thus, S. Daniel Breslauer expresses a shared Jewish and Christian understanding of the Sabbath:

it is holy because it is shared with God. The holiness of Sabbath and holidays is not static but dynamic - it depends on the meeting between the divine and the human. (Breslauer \& Deutsch 1995:87)

We can see the same emphasis on relationship in the language of Christian blessings, which locate holiness not in the object being blessed, but in the God Who blesses. Perhaps a fitting illustration in a discussion of humour can be found in the 1962 Roman Missal, in a blessing for beer. Throughout, the language acknowledges the connection to the Holy, even in simply referring to 'this creature, beer'. The prayer begins by affirming the relationship to God - 'Our help is in the name of the Lord. Who made heaven and earth' - and ends by invoking God's presence in human life - 'Grant that whoever drinks it with thanksgiving to your holy name may find it a help in body and in soul; through Christ our Lord' (Canons Regular of St. John Cantius 2010). Relationship is central again in William James's definition of 'saintliness' (the human embodiment of the holy, in Latin sanctus), in which each of his four criteria insists on connection to the transcendent and to others:

a feeling of being in a wider life than that of this world's selfish little interests; a sense of the friendly continuity of the ideal power with our own life; an immense elation and freedom, as the outlines of the confining selfhood melt down; and a shifting of the emotional centre ... towards 'yes, yes', and away from 'no', where the claims of the non-ego are concerned. (James 1997:220-221)

Just as nothing is holy apart from the Holy, so nothing is funny in itself; humour, too, exists only in relationship. Some have put forward theories of humour (and of its most 
common expression, laughter) that attempt to locate humour in some property of an object, most often incongruity (a helpful review is provided in Morreall 2014:124-126). But it is not difficult to imagine situations in which the most incongruous of jokes or acts, because it does not suit the human context, is simply not funny, as when a well-intended quip unwittingly evokes a sorrow carried by the listener. Conversely, relationship can allow the direst of human situations to be perceived with the lightness of Niebuhr's 'self-transcendence'. We find instances in what may be the second easiest way to connect humour and holiness, stories of the laughter of holy women and men. Exemplary is an 18th-century account of the blessed Sabina, in which the legendary martyr confounds her captors by laughing at the prospect of her imminent death: 'It pleases God', she explains, 'For we are Christians, and they who are in Christ with a firm and constant faith will laugh with everlasting laughter' (Screech 1999:50). Sabina's response recalls hagiographical traditions about St. Lawrence, which show the saint using humour against his Roman prosecutors in what Catherine Coonybeare has called 'antihegemonic hilarity' (2002:175). The most famous of these episodes is reported by Prudentius's Peristephanon. While he was being roasted alive, Lawrence quipped to his torturers that he should 'be turned over just before his death, as one side was already cooked' (Beard 2014:154-155); he then invited them to eat (Coonybeare 2002:195). Lawrence's humour may seem as dark as Sabina's is bright, but for both saints humour is a sign of a transformed relationship to earthly life. Lawrence remains a model of liberation from earthly conventions, so much so that at his shrine he answers prayers made in the form of laughter (Coonybeare 2002:197-198).

The vantage point of holy humour is not limited to hagiography. Rahner cites Clement of Alexandria's allegorical reading of the play shared between Isaac (whose name famously derives from the Hebrew for 'laughter') and his wife Rebecca (whose name Rahner translates as 'perseverance'). The scene, Clement writes, encourages the faithful towards 'rejoicing and laughing over our salvation, just as Isaac did' (Paedagogus, I, 5, 22, 1, cited in Rahner 1965 [1949]:49). Isak Dinesen uses this trope splendidly in 'The Deluge at Noderney', in which the protagonist Kasparson, himself a kind of martyr, contrasts the current age of false gods with a laughter-filled eschaton in which the true god is revealed:

Heaven will ring and resound with laughter, pure and innocent as that of a child, clear as that of a bride, triumphant as that of a faithful warrior who lays down the enemy's banners at his sovereign's feet, or who is at last lifted from the dungeon and the chains, cleared of his slanderer's calumnies! (Dinesen 1934:26-27)

More recently, works geared to popular audiences have argued that 'our common lives are helped by both genuine religion and genuine humor' (Trueblood 1964:125), that 'humor as a virtue is grounded in the same conviction that grounds the other virtues - God is beneficent and sustains us in love' (Gula 2011:80) and that 'joy, humor, and laughter are at the heart of the spiritual life' (Martin 2011). In all these cases, laughter is a symbol of right spiritual relationship hopeful freedom within this world and trust in the world to come.

\section{The intimacy and virtue of humour}

Humour, then, can serve spirituality in religious satire, and it can express a self-transcending relationship to the holy. But humour's relational nature is most often expressed in the daily complexities of human relationships, and there holiness can be especially hard to see. If spirituality seeks not only the understanding of but the nurturing of the human spirit, then we need to ask not only whether humour can express right relationship to the holy, but whether humour, as it participates in human relationships, can help humans become holy. Philosopher Ted Cohen provides a helpful start in his analysis of a particular humorous relationship, joke-telling:

When you offer your joke, you solicit [your hearers'] knowledge, you elicit it, in fact, virtually against their will, and they find themselves contributing the background that will make the joke work. Thus they join you. And then they join you again, if the joke works, in their response, and the two of you find yourselves a community, a community of amusement. This is what I call the intimacy of joking. (Cohen 1999:40)

Cohen describes here two aspects of the relationality inherent in humour. Firstly, humour relies on shared background knowledge. Bishop Dowling's joke provides an example. To have a basic understanding of the joke, the audience must recognise that the punch line quotes the Bible, and they must know that when Jesus spoke of casting out the devil through prayer and fasting he meant something rather different than the joke's bishop-besting priest did. To understand the joke more fully - in particular, to appreciate its various exaggerations - a listener would also need to know something about other elements of spirituality: the virtue of hospitality, the structures of religious communities, asceticism in food and sleep, the Holy Office and the virtue of visiting the suffering. In this shared knowledge lies the most basic level of relationship that humour requires. Having this background does not assure that the audience will find the joke funny, but without that shared knowledge, humour is impossible.

Shared knowledge may constitute a fairly superficial degree of relationship, but Cohen's analysis next points to a more substantive connection: the 'joining' of joke-teller and audience in a shared, embodied expression of humour, namely laughter or smiling. Cohen fully recognises that along with this possibility comes the risk of its opposite: if you don't like my joke, you will fail to join me, and instead of creating or reinforcing community, I may be more isolated than I was. Thus, what Cohen calls 'the intimacy of joking' entails, like all intimacy, a degree of vulnerability on either side. The teller of the joke risks isolation or even reproach. Meanwhile, the audience of a joke is 'virtually compelled to supply' the background knowledge the joke requires; in fact, the hearers do this 'automatically, without even considering whether they would like to be thus pulled in'. 
The consequence of this automatic mental process is that it is possible for a listener to be amused at a joke, even to 'join' the teller in a smile or laugh, before fully realising that the shared knowledge just supplied is not knowledge she's proud of. A listener may laugh at a joke that's based on a stereotype or prejudice or cruelty because she's performed - 'virtually against [her] will' - the mental work that allows her to understand the joke, perhaps appreciate its cleverness and express her understanding in the conventional response of laughter. Then she finds that, unwittingly, she has just joined a community of which she is ashamed to be a part.

All this suggests that if there is, as Cohen claims, an intimacy in humour, there is also an ethics of humour. Unlike holiness, which by its nature expresses a right relationship between the Holy and the blessed, humour may express any number of relationships among those who participate in it, and some are more moral, and potentially more conducive to holiness, than others. To explore how ethical humour might enable holiness, we can consider in more depth the two moments Cohen identifies in a joking relationship. The first is the starting point of humour, the shared knowledge that allows us to recognise something as funny. By evoking our background knowledge - what we have been enculturated, or perhaps have chosen, to know and believe - our senses of humour reveal ourselves to ourselves and sometimes to others. Students of humour debate whether we can laugh at a joke without actually endorsing its premises (Lengbeyer 2005; Smuts 2009). But if we are to use humour as a way towards holiness, it is certain that we will not always be pleased to find what amuses us. We are right at that point to welcome with humility the gift of self-knowledge that humour provides. Without it, we cannot repent, and without repentance, human holiness - the righting of relationship with the Holy - is impossible. As Robert Schreiter writes, it is the Holy itself that reconciles the repentant: 'reconciliation is the work of God, who initiates and completes in us reconciliation through Christ' (Schreiter 1998: 14; italics in original). In this way humour can surely serve, as Niebuhr says, as the 'prelude to contrition'.

In the next moment, once humour has evoked our knowledge, we offer our response: we join others in amusement, or we do not. Here we might recall the fourth book of the Nicomachean ethics (1128a-b), in which Aristotle defines virtuous humour, or eutrapelia. Eutrapelia has a deeply relational meaning, literally 'well-turning' (Rahner 1965 [1963]:93-94) or 'ease at turning', with an implication of 'flexibility, adaptability, easy-going character' and 'an ability to adapt one's humour quickly to the shifting requirements of banter' (Halliwell 2008:312). As usual, Aristotle situates the virtue as the mean between extremes, which are usually rendered in English as boorishness, or rigid resistance to humour, and buffoonery, or excessiveness and crudeness in humour (Aristotle 1962:107-108; Halliwell 2008:311; Rahner 1965 [1949]:93-94). We have already borrowed from Hugo Rahner's lovely book Man at play: Or, did you ever practice eutrapelia?, which urges Christians to recover the virtue of eutrapelia. Indeed, this idea of virtuous humour as turning well is very promising for those interested in holiness. Firstly, despite the 'automatic' workings of some aspects of humour, the notion of humour as a virtue offers the possibility that holy humour can be cultivated, and that we can train our responses away from prejudice and cruelty and towards right relationship. Secondly, eutrapelia sees in humour an agility that reminds us of holiness. Virtuous humour responds to the unexpected with an openness grounded in the recognition that we do not fully control what is around us. Such an attitude can open a way to the transcendent, and at its best it can express itself in the conversion - the well-turning - of our lives. G.K. Chesterton describes this agility perceptively in The man who was Thursday: A nightmare. The hero, Gabriel Syme, suddenly perceives that the enemy he has been fleeing is in fact an ally, that he has staked his life on flight and been wrong. At that moment, Chesterton writes, 'He knew simultaneously that he was a fool and a free man'. As the awareness dawns, he faces his world with 'a certain healthy humiliation'. Chesterton (1999) continues:

There comes a certain point in such conditions when only three things are possible: first a perpetuation of Satanic pride, secondly tears, and third laughter. Syme's egotism held hard to the first course for a few seconds, and then suddenly adopted the third. (pp. 131-132)

This agility, this ability to acknowledge and respond to what is beyond us, seems kindred to the humble openness that is required in an encounter with the holy. Perhaps this could be a small example of the paradigm Kees Waaijman sees in Moses' removing his shoes, ceding his claim to the earth as he enters the presence of the one who says I AM (Waaijman 2015). In fact, given what we later learn about Syme's mysterious adversary, who finally identifies himself as 'the Sabbath ... the peace of God' (Chesterton 1999:260), this seems quite likely. We can trace the paradigm of responsiveness through the Biblical tradition, particularly if Celia Deutsch is right that 'The fundamental reality of Christian holiness is that of grace, of discipleship' (Breslauer \& Deutsch 1995:90). Abram forsaking his home and becoming Abraham; Naomi following Ruth; Mary receiving the word of the angel; the fishermen, tax collectors and marginalised leaving nets, families and oppression to follow Jesus; the fervent young man from Tarsus who becomes the apostle Paul - all express the willingness to submit to surprise in the service of right relationship with God and others.

\section{The evolution of humour}

Humour and holiness, then, both require not only relationship, but the ability to enter relationship with openness. Cognitive science, which has taught spirituality a good deal in recent years, suggests that such inner agility may be ancient, even innate, in humanity. Researchers Matthew M. Hurley, Daniel C. Dennett and Reginald B. Adams, Jr., in their MIT-published study Inside jokes: Using humor to reverse-engineer the mind, propose that humour may have given early humans evolutionary advantages, developing as a mechanism to reward problem-solving. 
A joke can illustrate their point: What do Winnie the Pooh and Alexander the Great have in common? Hurley and company propose that, when faced with a puzzle like this, our minds generate and test an abundance of possibilities (Hurley, Dennett \& Adams 2011:120-121). For instance, we might run through all the similarities we can think of between Winnie and Alexander; we might also look for tricks, puns or some bit of context we might have missed. Then we hear the answer: 'Same middle name'. Our minds naturally go through the process again, rapidly investigating any way to make sense of the punch line (Middle name? They don't have a middle name, they just have ... ohhh). All the mind's work, moving with impressive speed through all those possibilities, converges on the little word 'the'.

When we do this, Hurley and company argue, we are doing what evolution has shaped us to do (Hurley et al. 2011:127, 290-292). If an ancient human spies a hungry predator, his mind will look for any possible means of escape, quickly evaluating each until - with luck - he finds one that will bring him to safety. In order to reinforce this life-saving process, our minds reward us with pleasure when we solve puzzles, even puzzles that in themselves are not matters of life and death. Humour expresses that pleasure. This model supports Cohen's contention that jokes elicit background knowledge even without our consent: Our brains have evolved to seek and provide the knowledge we need and then make sense of the punch line, and they will do so even if the knowledge we need is knowledge we would rather disavow.

To say that the inner workings of humour may be innate to our species is not to say that they are profane. If humour is a natural way for us to respond to problems, if it's a kind of agility bred in us like the fear of predators, it may be natural that we should turn to humour when we face our most urgent and important questions, among them the mystery of God. Far from being too light for this task, humour is in fact one of the tools we have to confront matters of life and death. Again, Chesterton puts it well:

Life is serious all the time, but living cannot be. You may have all the solemnity you wish in your neckties, but in anything important (such as sex, death, and religion), you must have mirth or you will have madness. (Donnelly 1992:385)

Humour expresses a responsiveness that is evident in Sabina and Lawrence, in Syme and Kasparson, and that can infuse daily attentiveness to the Holy, as well.

This account of humour, then, connects to holiness on one level, namely that both involve the individual's responsiveness to something beyond him or her. Researchers like Oxford's Robin Dunbar have hypothesised that humour's evolution also points towards humanity's communal nature, an essential dimension of spirituality. They propose that the capacity to joke together may have given early humans a different evolutionary advantage, one grounded in relationship: humour enables humans to overcome social tensions, and energetic laughter releases the hormone oxytocin, best known for its production during sex, which fosters bonding (Ghosh 2011). Humour's diplomatic and hormonal effects may have allowed humans to form large groups that offered more protection than other primates were able to achieve, and thus to survive and flourish. According to Joseph Polimeni and Jeffrey P. Reiss, Dunbar hypothesises that humour and laughter became important as language evolved to 'eventually replace [...] social grooming as the principal social bonding device between hominids' (Polimeni \& Reiss 2006:352). Humour thus not only participates in the daily exchanges of human relationships; it may have been instrumental in creating the capacity for human relationships in the first place.

\section{The laughter of devils and angels: Humour's ambiguity}

Humour contributes to relationships, but it can damage them as well. An important reason lies in humour's persistent ambiguity, which is grounded in humour's relational nature. For instance, if we didn't know the context in which Bishop Dowling's joke was told, it would not be completely clear whether it was intended to mock the duped bishop or the wily priest, or if it aimed to critique religious hypocrisy more broadly, or even if it targeted religion itself. Given humour's relational nature, it's possible to imagine social situations in which the joke could be told with any of these intents.

Another reason for the ambiguity of humour derives from its association with laughter. To be sure, we do well to distinguish between laughter and humour, both because laughter can express more than humour (for instance, relief, embarrassment, delight, surprise, absurdity, even pain) and because humour does not need to be expressed physically. But if humour has one preeminent mode of expression, laughter is it, and the reputations of humour and laughter have often fared well or ill together. So it is worth our while to explore laughter a bit further and see how it might shape humour's connections with holiness.

Laughter is complex enough that a variety of religious stories have arisen to account for its ambiguity. In one of the most thought-provoking, Milan Kundera's parable ('On Two Kinds of Laughter'), laughter initially belonged to the devil, who used it to scorn God and God's creation. An angel, hearing the assault and knowing he had to respond, simply imitated the devil's action: 'Opening his mouth, he emitted broken, spasmodic sounds in the higher reaches of his vocal range'. But he tried to:

giv[e] them an opposite meaning: whereas the devil's laughter denoted the absurdity of things, the angel on the contrary meant to rejoice over how well ordered, wisely conceived, good, and meaningful everything below was.

The angel's attempt at laughter was a mixed success: ridiculously inept, it increased the devil's laughter; yet it also 
freed laughter at least partially from the devil's grip. As a result, Kundera writes, the angel's:

imitation of laughter and (the devil's) original laughter are both called by the same name. Nowadays we don't even realize that the same external display serves two absolutely opposed internal attitudes. There are two laughters, and we have no word to tell one from the other. (Kundera 1996:87)

In fact, there are more than two laughters; there are innumerable laughters, and laughter is as a result notoriously difficult to interpret correctly. As with humour, then, we cannot embrace all laughter as virtuous or condemn it as vicious. We need instead to make distinctions, because, unlike holiness, laughter can express and create a range of relationships.

Kundera's story depicts the difference between laughter that derides and establishes a relationship of separation - what we often call 'laughing at' - and laughter that establishes a relationship of affiliation - 'laughing with'. Christian practice and theology give witness to the same distinction. In the tradition of risus paschalis, laughter seems to process past Niebuhr to find a home in the holiest of Christian liturgies. As the then Joseph Cardinal Ratzinger explains, in a Baroque tradition:

The Easter homily had to contain a story that made people laugh, so that the church resounded with a joyful laughter ... that laughter which testified to the freedom of the redeemed. (Ratzinger 1997:50)

This laughter of heavenly joy, which echoes that of Sabina and Lawrence, is not the only laughter that has been used to describe the world to come. For instance, Tertullian's vision of eschatological redemption consists in large part of revenge:

How vast a spectacle then bursts upon the eye! What there excites my admiration? what my derision? Which sight gives me joy? which rouses me to exultation? - as I see so many illustrious monarchs, whose reception into the heavens was publicly announced, groaning now in the lowest darkness with great Jove himself, and those, too, who bore witness of their exultation; governors of provinces, too, who persecuted the Christian name, in fires more fierce than those with which in the days of their pride they raged against the followers of Christ. (Tertullian 1998:XXX)

While Ratzinger points to a joyful laughter that brings into relationship, uniting 'the redeemed', Tertullian laughs to deride, excluding those he considers his enemies. No doubt, however, each author means to offer a vision of the holy.

The Bible is similarly ambivalent, including Sarah's rejoicing that the birth of Isaac ('laughter') will cause others to laugh with her (Gn. 21:6), the triumphant laughter of the restored exiles (Ps. 126) and the eschatological laughter of those who suffer on earth (Lk. 6:21), but also God's laughing the nations to scorn (Pss. 2, 37 and 51) and the earthly laughter that will be repaid with eschatological woe (Lk. 6:25). These examples confirm the relational complexity of humour: not only can humour and laughter deride or welcome, but they can be directed at both the just and the unjust. Thus, while Church fathers are right to observe that the gospels never explicitly record Jesus' laughter (Screech 1999:47), the evangelists certainly make it possible to imagine Jesus laughing playfully to welcome children and laughing rather more sharply at adults who are guilty of hypocrisy. Humour can help humans pursue holiness in their daily relationships, but it is crucial to distinguish among the intents and targets of humour.

\section{Humour and the religious imagination}

Humour, then, plays a complex role in human relationships, one that may nurture or turn from holiness. A further connection between humour and holiness lies in the possibility that humour might help us imagine the divine. Images of the divine contribute powerfully to spirituality, for good or ill. As Bryan Massingale (2010) writes:

Vision, image, and metaphor express more than discursive media can convey ... They have a surplus of meaning that is always unfolding and never definitely comprehended. Metaphors and images have a dynamic character; they appeal to the imagination and inspire creative thought and action. (p. 136)

When the religious imagination makes use of humour, it opens itself to humour's complexity and relationality. The result is a particular ability to challenge established images and to invite fresh theological reflection and ethical action.

A perennially debated example is the Talmudic story of the Oven of Achnai from tractate Baba Mezi'a 59b. The sages are arguing over a point of law on which all agree except for Rabbi Eliezer. Rabbi Eliezer calls on the surrounding creation to witness that he is right. At his request, a carob tree hurls itself a hundred cubits ('others affirm, four hundred cubits'), a stream reverses its course and the walls of the schoolhouse lean towards the earth. When none of these miracles sways the other rabbis, a Heavenly Voice thunders down to support Eliezer: 'Why do ye dispute with R. Eliezer, seeing that in all matters the halachah agrees with him!' But Rabbi Joshua responds to the voice by saying, 'It is not in heaven' - in other words, the law was given to God's people on Sinai, with the command that the majority should decide, and it is by that command that they must act. Some time later, the Talmud continues:

Rabbi Nathan met Elijah and asked him: What did the Holy One, Blessed be He, do in that hour? Elijah answered, He laughed, saying 'my children have defeated me, my children have defeated me'. (Cohen 1999:56-57; Cunningham \& Katzew 2013:55-56)

The story records God's laughter, but it does not explain it: the rabbis do not tell us, for instance, whether the tone of God's laughter is that of parental exhaustion, Psalmic laughter to scorn, recognition of absurdity or joyful embrace of his offspring. In other words, the symbol of holy laughter leaves it to the reader to interpret how the humour here might express and nurture the relationship between the mortal and the Holy. Most agree with Jan Katzew that 'God 
was delighted by this display of rabbinic authority and its triumph over divine will. God and the rabbis are partners, and as in any collaborative partnership, the balance of power shifts from time to time' and with Philip A. Cunningham that 'God is pleased to the point of laughing in joy that his children, Israel, ... have assumed responsibility for being God's covenantal partners in living out a holy life' (Cunningham \& Katzew 2013:56-57). But some, among them Cohen, hear divine derision at the humans' audacity: 'I say that they have committed some kind of absurdity, and I laugh. Elijah reports that so did God. Well, what else was He to do?' (Cohen 1999:57). The laughter in the story may provide an image of God's loving affirmation of human independence or of God's derisive judgement of human hubris. In either case, though, it resists any tidy or sure view of the divine.

In a more contemporary example of humour's ambiguous depiction of holiness, the television show The Simpsons has been remarkable for the complexity with which it treats religion. In one episode, God leaves a conversation with Homer because he needs to head to Mexico and appear in a tortilla. Mark I. Pinsky, author of The Gospel According to the Simpsons, analyses the ambiguity: 'Is this a dig at believers who report seeing pious visions in unlikely places? Clearly not, because God says he will actually be present in the tortilla' (Pinsky 2007:22). The series' fundamental respect for the divine is suggested by the fact that, as creator Matt Groening has pointed out, every character in the show is drawn with a thumb and three fingers, with one exception: the only character who has all five fingers is God. At the same time, the God of The Simpsons is recognisably ambivalent: as Homer says of God, 'he's always happy. No wait, He's always mad' (Pinsky 2007:18). It's possible to say that The Simpsons is not an especially sound source for theological reflection, but it is difficult to deny that the same ambivalence appears throughout the history of spirituality.

\section{Conclusion}

\section{Humour and the work of justice}

Christian spirituality has often been wary of humour, assuming that the holy requires the serious. But perhaps especially for that reason, humour may refresh our theological imaginations. Images like Sabina's, the Talmud's, Groening's or Dinesen's may use humour in ways that awaken and invigorate our understanding of the holy. In part this is because the ambiguity of humour - as frustratingly difficult as it can be to read - actually suits it to imagining the holy: because of its ambiguity, humour can never give us the impression that it's describing God with complete accuracy, or even the fallible accuracy of more systematic theological discourse. So humour in depictions of the holy can perform an iconoclastic function, warning us against misreading. When it mocks God, it mocks an idol, and us as idolaters. This is the laughter that Syme embraces when he recognises how wrongly he has interpreted his erstwhile enemy and instead begins to perceive him as 'like a father playing hideand-seek with his children' (Chesterton 1999:247).
Humour thus approaches the holy with a humility ready to respond to that which is beyond us. Moreover, as Hurley and his colleagues suggest, humour may even be a reward for that responsiveness, a pleasure bred in humanity from its earliest days. If that is right, then there is another reason humour may be especially suited to imagining the holy: because it can inspire something of the delight it tries to describe. Thus, beyond merely opening up and purifying the religious imagination, humour can sustain our desire for the holy.

In the pages above, I have suggested that humour can satirise hypocrisy and reveal ourselves to ourselves, pointing out where we may harbour prejudice and be willing to exclude from community and compassion. It can also express a saintly self-transcendence, an open and joyous attitude towards the Holy. Further, it can help us imagine the holy in ways that resist idolatry and affirm the delight of the holy. Because the imagination, as Massingale argues, is crucially connected to the work of justice, it follows that, at its best, the relational nature of humour can help us do the ethical work that flows from, is an integral expression of and can nurture human holiness.

In all of these ways, humour, with its capacities both to mock and to embrace, can, as Majken Sorensen has put it, serve as a 'powerful strategy of nonviolent resistance to oppression' (Amarasingam 2010:468). In North America as elsewhere, as Amarnath Amarasingam has shown, we can see this use of humour in the artistry of Muslim comics who counter Islamophobia by using humour to foster understanding of Islam and to build community among Muslims and nonMuslims (2010). Despite the fact that humour is notoriously culturally specific - not least because, as Cohen explains, it requires shared background knowledge - examples like Canada's successful sitcom Little Mosque on the Prairie and even our bishop joke (which travelled from Guatemala, with Bishop Rammazzini; to Rustenburg, with Bishop Dowling; to the U.S. Midwest, where Bishop Dowling passed it on) demonstrate that humour can encourage relationships across cultural difference.

That humour can indeed cross boundaries, and that humour can indeed encourage ethical lives, are sources of hope. Yet there are ways in which the work of ethics might at times require us to work against humour. When we find humour where we would rather not, say in a joke built on a stereotype or exclusion, Cohen proposes that it does no good to deny that the humour is there. Do not say 'that's not funny'. Admit that, in this world, now, it is funny. But then 'Try remaking the world so that such jokes will have no place, will not arise' (Cohen 1999:84). Remake the world, in other words, so that the stereotype withers and the only shared knowledge the joke evokes is a matter of history, renounced long ago. Such work is thoroughly earth-bound, yet it is truly holy work. Along the way, perhaps in iconoclastic stories of bishops or five-fingered Gods, or even if we simply laugh together at a joke about Winnie the Pooh, humour might give us glimpses of the eternal laughter of the world to come. 


\section{Acknowledgements}

Sincere thanks to Pieter G.R. de Villiers and to the other conference organisers in SPIRASA, and to Andries G. van Aarde for organising the research project on holiness.

\section{Competing interests}

The author declares that she has no financial or personal relationships which may have inappropriately influenced her in writing this article.

\section{References}

Amarasingam, A., 2010, 'Laughter the best medicine: Muslim comedians and social criticism in post-9/11 America', Journal of Muslim Minority Affairs 30(4), 463-477. $\mathrm{http} / / / \mathrm{dx}$.doi.org/10.1080/13602004.2010.533444

Aristotle, 1962, Nicomachean ethics, transl. M. Ostvald, Macmillan, New York.

Beard, M., 2014, Laughter in ancient Rome: On joking, tickling, and cracking up, University of California Press, Berkeley, CA.

Breslauer, S.D. \& Deutsch, C., 1995, 'Holiness', in L. Klenicki \& G. Wigoder (eds.), A dictionary of the Jewish-Christian dialogue, expanded edn., pp. 86-92, Paulist Press, New York.

Canons Regular of St. John Cantius, 2010, Sancta missa, viewed 15 May 2015, from http://www.sanctamissa.org/en/resources/books-1962/rituale-romanum/54blessings-of-things-designated-for-ordinary-use.html

Chesterton, G.K., 1999, The annotated Thursday: G.K. Chesterton's masterpiece, 'The man who was Thursday', annotated by Martin Gardner, Ignatius Press, San Francisco, CA

Cohen, T., 1999, Jokes: Philosophical thoughts on joking matters, University of Chicago Press, Chicago, IL.

Coonybeare, C., 2002, 'The ambiguous laughter of Saint Laurence', Journal of Early Christian Studies 10(2), 175-202. http://dx.doi.org/10.1353/earl.2002.0018

Cunningham, P.A. \& Katzew, J., 2013, 'Texts and commentary', in P. Valkenberg (ed.) World religions in dialogue: A comparative theological approach, pp. 48-66, Anselm Academic, Winona, MN.

Dinesen, I., 1934, Seven Gothic tales, Quality Paperback Book Club, New York.

Donnelly, D., 1992, 'Divine folly: Being religious and the exercise of humor', Theology Today 48, 385-398. http://dx.doi.org/10.1177/004057369204800402

Dowling, K., 2015, e-mail, 13 May, diocrust@mweb.co.za.

Ghosh, P., 2011, 'Study reveals laughter really is the best medicine', BBC News, 13 September, 2011, viewed 01 May 2016, from http://www.bbc.com/news/ science-environment-14889165
Godzieba, A., 2015, e-mail, 13 May, anthony.godzieba@villanova.edu.

Gula, R.M., 2011, The way of goodness and holiness: A spirituality for pastoral ministers, Liturgical Press, Collegeville, MN.

Halliwell, S., 2008, Greek laughter: A study of cultural psychology from Homer to early Christianity, Cambridge University Press, Cambridge.

Hurley, M.M., Dennett, D.C. \& Adams, R.B., Jr., 2011, Inside jokes: Using humor to reverse-engineer the mind, The MIT Press, Cambridge, MA.

James, W., 1997, The varieties of religious experience: $A$ study in human nature, with a new introduction by Reinhold Niebuhr, Touchstone/Simon \& Schuster, New York.

Kundera, M., 1996, The book of laughter and forgetting, transl. A. Asher, HarperPerennial, New York.

Lengbeyer, L., 2005, 'Humor, context, and divided cognition', Social Theory and Practice 31(3), 309-336. http://dx.doi.org/10.5840/soctheorpract200531316

Martin, J., 2011, Between heaven and mirth: Why joy, humor, and laughter are at the heart of the spiritual life, HarperOne, New York.

Massingale, B.N., 2010, Racial justice and the Catholic Church, Orbis, Maryknoll, NY.

Merton, T., 1960, The wisdom of the desert: Sayings from the desert fathers of the fourth century, New Directions, New York.

Morreall, J., 2014, 'Humor, philosophy and education', Educational Philosophy \& Theory 46(2), 120-131. http://dx.doi.org/10.1080/00131857.2012.721735

Niebuhr, R 1946, 'Humour and faith', in Discerning the signs of the times: Sermons for today and tomorrow, pp. 111-131, Charles Scribner's Sons, New York, viewed $30 \mathrm{Apr}$ 2016, from http://www.luc.edu/faculty/pmoser/idolanon/ NiebuhrDiscerning.pdf

Pinsky, M.I., 2007, The gospel according to The Simpsons, 2nd edn., Westminster John Knox Press, Louisville, KY.

Polimeni, J. \& Reiss, J.P., 2006, 'The first joke: Exploring the evolutionary origins of humor', Evolutionary Psychology 4, 347-366. http://dx.doi.org/10.1177/147 470490600400129

Rahner, H., 1965 [1949, 1963], Man at play: Or did you ever practise eutrapelia? transl. B. Battershaw \& E. Quinn (1965), Burns \& Oates, London.

Ratzinger, J.C., 1997, 'Easter: Sarah's laughter', in Images of hope: Meditations on major feasts, transl. J. Rock \& G. Harrison, pp. 43-52, Ignatius Press, San Francisco, CA.

Schreiter, R.J., 1998, The ministry of reconciliation: Spirituality and strategies, Orbis, New York.

Screech, M.A., 1999, Laughter at the foot of the cross, Westview Press, Boulder, CO.

Smuts, A., 2009, 'The ethics of humor: Can your sense of humor be wrong?', Ethical Theory \& Moral Practice 13, 333-347. http://dx.doi.org/10.1007/s10677-0099203-5

Tertullian, 1998, 'The shows, or De spectaculis,' in Christian classics electronic library transl. S. Thelwall, viewed 01 May 2016, from http://www.tertullian org/anf/ anf03/anf03-09.htm\#P890_350630

Trueblood, E., 1964, The humor of Christ, Harper \& Row, New York.

Waaijman, K., 2015, 'Spirituality in the 21st century', paper presented at the Society for the Study of Christian Spirituality and Spirituality Association of South Africa bi-annual meeting, St. Augustine College, Johannesburg, 20-24th May. 